Primljen / Received: 25.6.2016.

Ispravljen / Corrected: 2.9.2017.

Prihvaćen / Accepted: 30.10.2017.

Dostupno online / Available online: 10.1.2018.

\section{Refined NSA approach for seismic assessment of regular RC frames}

Authors:

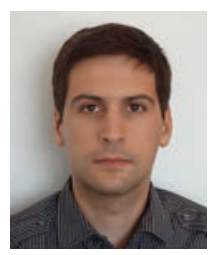

Szabolcs Varga, PhD. CE V\&V Projekt srl, Romania varga.szabolcs@vvp.ro

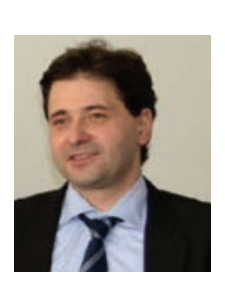

Prof. Cosmin G. Chiorean, PhD. CE Technical University of Cluj-Napoca, Romania cosmin.chiorean@mecon.utcluj.ro

\section{Szabolcs Varga, Cosmin G. Chiorean}

Subject review

\section{Refined NSA approach for seismic assessment of regular RC frames}

The nonlinear time-history analysis is often a time-consuming and impractical procedure. A new computer method, developed in the framework of the Eurocode 8 is proposed in this paper. It is based on the determination of both structural capacity - using pushover analysis - and seismic demand - using nonlinear time-history analysis of a single-degree-of-freedom system. An emphasis is placed on the effect of different lateral load distribution on capacity determination, and on the effect of hysteretic models on the determination of seismic demand.

Key words:

pushover analysis, hysteretic models, constant strength inelastic spectrum, constant ductility inelastic spectrum

Pregledni rad

\section{Szabolcs Varga, Cosmin G. Chiorean}

\section{Prijedlog seizmičke procjene pravilnih AB okvira}

Nelinearni dinamički proračun s primjenom vremenskog zapisa, često vrlo dugo traje i nije praktičan. U radu se predlaže nova računalna metoda razvijena u okviru Eurokoda 8. Metoda se temelji na određivanju kapaciteta konstrukcije pomoću metode postupnog guranja, i seizmičkog zahtjeva primjenom nelinearnog dinamičkog proračuna s vremenskim zapisom za sustav s jednim stupnjem slobode. Posebno se razmatra utjecaj raspodjele horizontalnog opterećenja na određivanje kapaciteta, te utjecaj histereznih modela na odgovor sustava pri određivanju seizmičkog zahtjeva.

Ključne riječi:

metoda postupnog guranja, histerezni modeli, neelastični spektar kontinuirane čvrstoće, neelastični spektar kontinuirane duktilnosti

Übersichtsarbeit

Szabolcs Varga, Cosmin G. Chiorean

Vorschlag für eine seismische Beurteilung von vorschriftsmäßigen Stahlbetonrahmen

Die nichtlineare dynamische Berechnung mit Aufzeichnung des zeitlichen Ablaufs, dauert oft sehr lange und ist nicht praktisch. In der Arbeit wird eine neue Rechenmethode vorgeschlagen, die im Rahmen von Eurocode 8 entwickelt wurde. Sie beruht auf der Festlegung der Konstruktionskapazitäten anhand der Pushover-Methode und der seismischen Anforderungen anhand einer nichtlinearen dynamischen Berechnung mit Aufzeichnung des zeitlichen Ablaufs für Systeme mit einem Freiheitsgrad. Insbesondere wird die Auswirkung der Verteilung der horizontalen Belastung auf die Festlegung der Kapazität erwogen sowie der Einfluss der Hysterese-Modelle auf die Antwort des Systems bei der Festlegung der seismischen Anforderungen.

Schlüsselwörter:

Pushover-Analyse, Hysterese-Modelle, unelastisches Modell der kontinuierlichen Festigkeit, unelastisches Modell der kontinuierlichen Duktilität 


\section{Introduction}

\subsection{Current nonlinear static analysis (NSA) methods}

In earthquake engineering, it is very well known that nonlinear time-history analysis (NTHA) methods generally provide more realistic numerical models for the nonlinear structural response of structures subjected to strong earthquakes. Theoretically, it is expected that such methods can provide more reliable assessment of earthquake performance compared to other approaches such as nonlinear static analysis methods (NSA). Despite that, the NTHA model might be a solution for seismic performance evaluation, although due to its complexity and high number of parameters involved in data entry, and as this approach usually goes beyond the framework of practical application, it seems to be appropriate for research purposes only. In addition, the obtained results are not always more reliable due to uncertainties related to input data. The use of the NTHA for real large scale building structures still represents a formidable task despite development of computer technologies, as it requires a set of carefully selected ground motion records. Furthermore, as the current knowledge on site seismicity is quite limited, it is highly difficult to identify variability in earthquakeinduced demands due to hazards and uncertainties in the ground motion intensity, arising from frequency content and duration of ground motions of a given intensity. Moreover, the NTHA accuracy is strongly influenced by the mathematical model representation of actual behaviour of structures, and by modelling parameters such as the inelastic (hysteretic) behaviour at the fibre of cross-section, modelling detail at the cross-sectional level, nonlinear stress-strain constitutive relationships for concrete (confined or unconfined) and reinforcing steel, damping, mass-distribution, etc. It is important to stress that the distributed plasticity approach rather than the concentrated plasticity (plastic hinge) approach has to be considered in a valuable nonlinear inelastic analysis of RC frame structures [1,2] due to high spread of plasticity throughout the volume of the members and, hence, the computational effort will increase significantly due to the necessity to monitor hysteretic behaviour at the fibre level, i.e. some limitations will be revealed, from computational point of view, with regard to real large scale buildings. Another aspect concerning reliability of the NTHA application for evaluation of seismic performance is represented by the effects of dynamic soil-structure interaction (SSI) and the nonlinear behaviour of the surrounding soil. The influence of SSI effects on the seismic performance evaluation of structures has recently been studied in greater detail. These studies have revealed the importance of using complex models in which fully nonlinear behaviour of soil and structures is considered, especially for structures founded in zones with considerable ground deformations or soil liquefaction [3]. Consequently, excessive sophistication in mathematical modelling of structural nonlinear analysis without considering soil-structure interaction in analysis is not warranted and, also, more advanced approaches may conceal serious and unforeseen pitfalls.

Recognising all these issues concerning the NTHA applicability for seismic performance evaluation of real large-scale reinforced concrete (RC) structures, the nonlinear static analysis (NSA) method has become in the last decade the focus of intense research efforts aimed at developing a practical yet accurate alternative approach both to the elastic seismic equivalent force approach provided by the main seismic codes, and NTHA approaches for the seismic design of structures. Current NSA methodologies for the seismic assessment of 2D RC frame structures have been applied to obtain seismic performance indicators that are in fair agreement with the more sophisticated nonlinear timehistory approaches, especially for structures that vibrate predominantly in the first mode. Due to their simplicity and less computational effort involved, such procedures are considered promising candidates for developing new and improved techniques for seismic performance evaluation of real large scale frame structures. However, despite considerable efforts deployed in recent years to develop sophisticated nonlinear static approaches aimed at improving correlation between the NSA and NTHA results, it is fair to say that static procedures will never be able to replace dynamic analyses. Yet, even when the NSA procedure is not appropriate for a complete performance evaluation, nonlinear static analysis can be an effective design tool to investigate the aspects of the analysis model and the nonlinear response that are difficult to do by a nonlinear dynamic analysis [4]. For instance, the NSA can be useful to:

- check and debug sophisticated nonlinear analysis models for complex structures;

- reveal main yield mechanisms and deformation demands (ductility) of structures, and also some deficiencies of improperly designed structures,

- conduct parametrical and sensitivity studies on different parameters defining material and geometrical properties of the structure and the ways in which these parameters affect the local and global behaviour of structures.

Following inclusion in the design codes (ATC-40 [5] FEMA 356 [6] and 440 [7] and Eurocode 8 (EC 8) [8]), as well as by the spread of advanced personal computers, the nonlinear static analysis (NSA) procedures have started to be widely used by structural engineers. They represent a link between the linear methods and more complex NTHA approaches, and are currently considered as the most computation-efficient solutions. The latter made it possible to determine with sufficient accuracy the inelastic displacements of new or existing structures. As already mentioned, unlike the NTHA, in the NSA applications, there is no need for complex entry data or time-consuming analyses. 
The first step in the NSA is the pushover analysis, in which the structure is subjected, at every step of loading, to either variable or invariable lateral forces. The result of the analysis consists in determination of the capacity (or pushover) curve, which synthesises the lateral deformation capacity of the MDOF structural system. With some exceptions like ATC40 or FEMA356, the design code-based NSA such as the one given in EC 8 recommends the use of invariable fixed and triangular lateral force distributions.

As stated above, if lateral forces are considered to be invariable, the results will be accurate only if structural response is not affected by higher modes of vibration and the structure has only one yield mechanism [9]. Due to the invariable lateral force distribution adopted by design codes, the deformed shape of the structure is also invariable. For example, for two earthquakes with different frequency contents, but which produce the same target displacement, the NSA with invariable force distribution indicates the same effort state. This limitation, which is due to static nature of the method, is widely accepted.

By recognising this latter aspect, several researchers have developed invariable force distributions by considering higher modes of vibration [10-12], as well as adaptive force distributions, which use quadratic modal combination procedures (SRSS/CQC) [13-15].

Advanced adaptive force distributions have been developed more recently. These can dispel inaccuracies due to the "always positive" character of incremental lateral forces, attributed to the use of modal combinations through the SRSS method $[16,17]$.

The second NSA step is the determination of the inelastic seismic demand, target displacement at global level, storey drifts, and rotations at local level. In agreement with EC8, after plotting the capacity curve using nonlinear static analysis, the smoothed design spectra are computed through simple empirical $R_{\mu}-\mu-T$ relations. It should also be noted that the code-based NSA procedures use smoothed design spectra for the inelastic seismic demand determination, and to determine inelastic displacements. In consequence, structural engineers do not have at hand a simple analytical method that would enable rapid determination of the nonlinear behaviour of structures for a set of accelerograms, in the framework of design codes [18].

According to an innovative approach proposed and assessed in this paper, the capacity of structures is determined through pushover analysis, while seismic demand is computed through response history analysis of an SDOF oscillator. Some researchers [19] also suggest the use of the NTHA within the Capacity Spectrum Method [20] (CSM) for the analysis of equivalent SDOF systems, although, apparently, it seems contradictory compared to static character of the CSM. In this respect, it is mentioned in [15] that, thanks to current equipment and computer technology, the NTHA of an SDOF system "is carried out in a fraction of a second", in contrast to
NTHA of the MDOF that is a more time-consuming analysis procedure.

Some features of the method proposed herein is also discussed in papers [1, 2]. The importance of a rigorous advanced nonlinear analysis in the determination of the capacity curve using nonlinear static analysis (NSA) methods is stressed in paper [1]. The influence of considering nonlinear physical and geometric effects was pointed out using an advanced NSA structural analysis algorithm, as described in detail in [1]. The proposed method has been validated in further studies and also in [2], where an emphasis is placed on the effect of the allure of the capacity curve, which depends mainly on the modelling and lateral load distribution.

Concerning previous works of the authors of $[1,2]$ where the effect of nonlinear modelling issues on pushover analysis is assessed, the focus is placed in the present article on nonlinear hysteretic modelling employed in the determination of inelastic response using the proposed innovative procedure. The effects of four types of hysteretic models in the determination of the SDOF demand are pointed out, and calculations employed for the determination of the inelastic demand are discussed in detail.

\subsection{Differences and similarities between the proposed procedure and other types of seismic analysis}

Conceptual differences between the proposed method (b), and the code-based NSA (a), and the NTHA (c), are highlighted in Figure 1. In the NTHA (c), the multi-degree of freedom (MDOF) structural system is subjected to the time-history record of an earthquake. The NTHA is the most computationally demanding analysis and is usually considered impractical for everyday use. In the present study, NTHA of the MDOF system is used for benchmark purposes only.

The first step of either the code-based NSA or the proposed method is the determination of capacity curve through pushover analysis. In the case of the code-based NSA (EC8), the inelastic seismic demand is determined through $\mathrm{R}_{\mu}-\mu-\mathrm{T}$ empirical formulas, while in the proposed method this is achieved through NTHA of the SDOF oscillator and representation of the constant ductility inelastic spectrum. Thus, regarding human or computational effort, the proposed method is very similar to the code based NSA, while it accounts for the actual frequency content of each earthquake record [1]. The determination of the inelastic spectrum directly from an accelerogram in conjunction with pushover analysis is also used in the "Yield Point Spectra" (YPS) method [22]. In the YPS the bilinear form capacity curve is plotted against the constant ductility spectra for several ductility values of the considered earthquake. From a conceptual point of view, the proposed method is thus similar to the YPS, except that the determination of inelastic demands is carried out more directly, 
a)

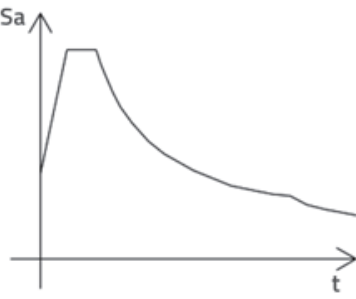

b) $\ddot{u}(\mathrm{t})$

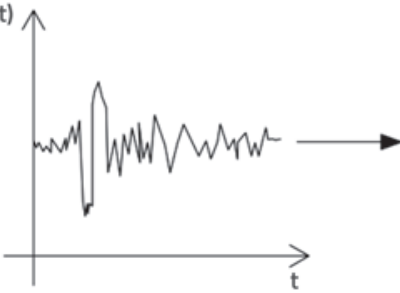

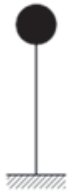
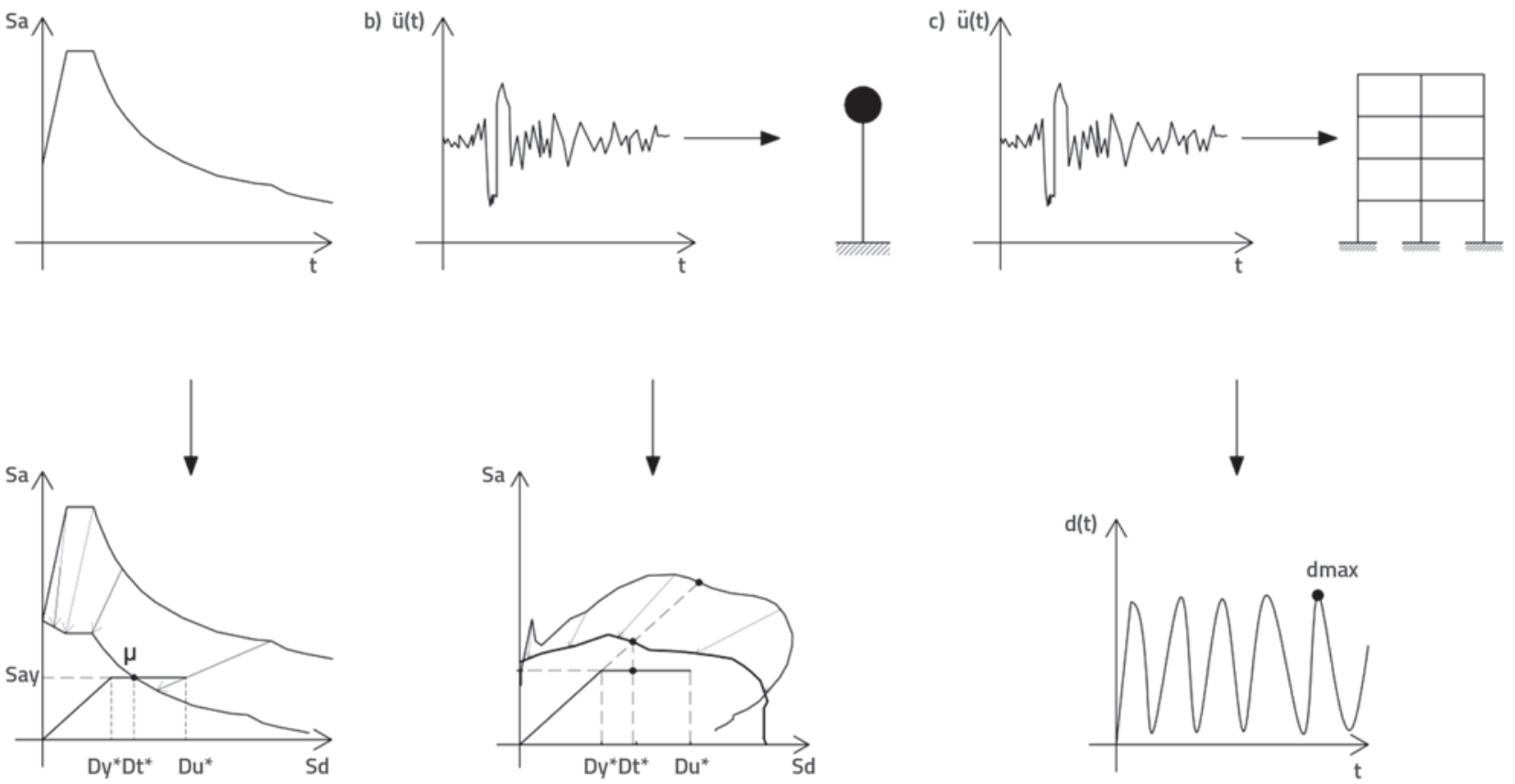

Figure 1. Comparison of principles employed in the determination of seismic displacements of structures using: a) code based nonlinear static analysis; b) proposed method; c) nonlinear time-history analysis

through numerical computation, without any graphical or analytical approximations. This novel feature of the method is detailed in Section 2. In addition, the YPS represents inelastic spectra in the seismic coefficient - yield displacement $C_{y}-D_{y}^{*}$ format, while the proposed method adopts the commonly used spectral acceleration-spectral displacement Sa-Sd format. Furthermore, the proposed method follows the steps of the well-known N2 method [23] when it comes to determining the capacity diagram of the equivalent SDOF, except that inelastic spectra generated from accelerograms are used instead of the inelastic spectrum obtained from design spectrum with the aid of empirical formulas [1].

Thus, the proposed method can be considered an extension of the methodology employed in EC8 in the directly generated inelastic spectrum case. Moreover, the proposed method is an equivalent and alternative to the YPS method, with the main advantages of the direct calculation of the constant ductility inelastic spectrum, and that graphical and analytical approximation are not required, as stated above.

\section{Proposed method for determination of inelastic seismic displacements}

\subsection{Determination of pushover curve and SDOF equivalent}

The key aspects of determining pushover curve in the present application are shown in Section 3.3. Ideally, any rigorously determined pushover curve can be used. It is recommended that physical and geometrical nonlinearities be adequately modelled
$[1,2]$. The user should also pay attention to the selection of lateral load distribution.

The transformation of capacity curve of the MDOF system into the bilinear capacity diagram of the SDOF system is implemented according to the principles of the N2 method (EC8).

\subsection{Inelastic response of SDOF oscillators}

The determination of ductility demand from intrinsic characteristics of the seismic record and those of the equivalent SDOF system is one of the key features of the presented procedure [1].

The response in non-linear domain is modelled using functions known as hysteretic models, which establish the response of the SDOF system according to its period of vibration, displacement and yield strength. The non-linear response of the SDOF system is obtained by solving Eq. (1). Since the function $\mathrm{f}_{\mathrm{s}}(\mathrm{u}(\mathrm{t}), \dot{\mathrm{u}}(\mathrm{t}))$ has a general form, the differential equation can be solved in its general form.

$$
\ddot{u}(t)+2 \xi \omega_{n} \dot{u}(t)+\omega_{n}{ }^{2} u_{y} \tilde{f}_{s}(u(t), \dot{u}(t))=-\ddot{u}_{g}(t)
$$

$\tilde{f}_{s}(u(t), \dot{u}(t))=\frac{f_{s}(u(t), \dot{u}(t))}{f_{y}}$

$\omega_{n}=\sqrt{\frac{k}{m}}$

$\xi=\frac{c}{2 m \omega_{n}}$ 
where $f_{s}(u(t), \dot{u}(t))$ is the force associated with the capacity of the SDOF system, and $\tilde{f}_{s}(u(t), \dot{u}(t))$ is the idealized variant of $f_{s}(u(t), \dot{u}(t))$ as related to the yield strength $\mathrm{f}_{\mathrm{y}}\left(\right.$ Eq. (2)); $\omega_{\mathrm{n}}$ is the pulsation of the system (Eq. (3)), and $\xi$ is the damping. (Eq. (4)) [24].

\subsection{Determination of constant strength inelastic spectrum}

With the aim of solving the nonlinear equations of motion, different methods are used for selecting the yield strength of the SDOF oscillator. These may lead to various types of inelastic spectrum, which can be inter alia be either constant ductility inelastic spectrum or constant strength inelastic spectrum [25]. The $\mathrm{R}_{\mu}$ elastic force reduction factor is used in order to determine the ductility demand characteristic of the SDOF system. The $R_{\mu}$ is the ratio between the elastic acceleration $\mathrm{S}_{\mathrm{ae}}\left(\mathrm{T}^{*}\right)$, and the yield capacity $\mathrm{S}_{\mathrm{ay}}$ expressed in the acceleration of the bilinearized equivalent SDOF system. Eq. (5) $T^{*}$ is the period of the SDOF equivalent and, like the bilinearized capacity diagram, it is computed using rules of the N2 method (EC8). The elastic spectrum $\mathrm{S}_{\mathrm{a}}(\mathrm{T})$ can be calculated through the linear response history analysis of SDOF oscillators, for the considered accelerogram.

Some uncertainties, like determination of the ductility demand of the SDOF replacement system, are eliminated using the NTHA of the SDOF system. On the other hand, in the N2 method, the ductility demand is calculated using empirical formulas.

An example of the elastic spectrum $\left(\mathrm{S}_{\mathrm{ae}}(T), \mu=1\right)$ plotted against the bilinear capacity diagram is given in Figure 2, where significance of the elastic force reduction factor $R_{\mu}$ is selfexplanatory.

$R_{\mu}=\frac{S_{a e}\left(T^{*}\right)}{S_{a y}}$

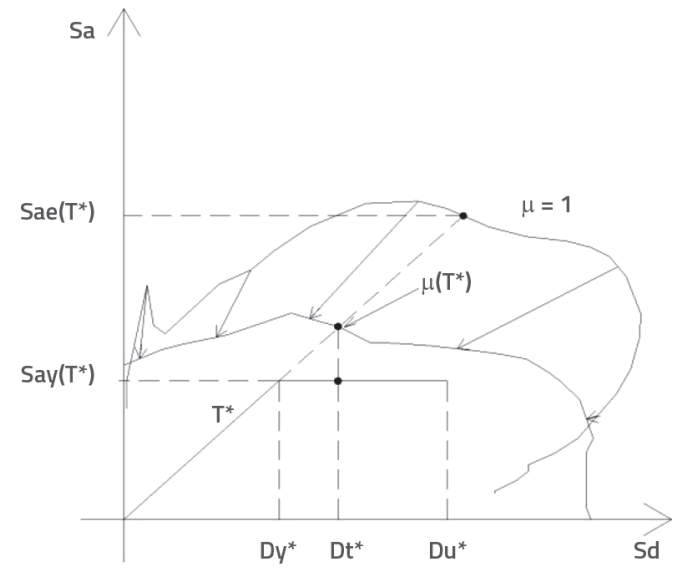

Figure 2. Determination of target displacement through graphical variant of the proposed method [1]

The $\mu$ ductility demand assigned to the $\mathrm{R}_{\mu}$ strength demand can easily be determined with the aid of the nonlinear response history analysis of the oscillator with constant $\mathrm{R}_{\mu}$ strength, conducted for the considered accelerogram [1]. The constant $R_{\mu}$ strength spectra show the ductility demand $\mu(T)$ for all SDOF systems characterised by the spectrum of $T$ periods (Figure 3 ). The ductility demand sought is the same as the displacement ductility achieved by the equivalent SDOF with R $\mu$ strength, at the period $T^{*}$, as depicted in Figure 3.

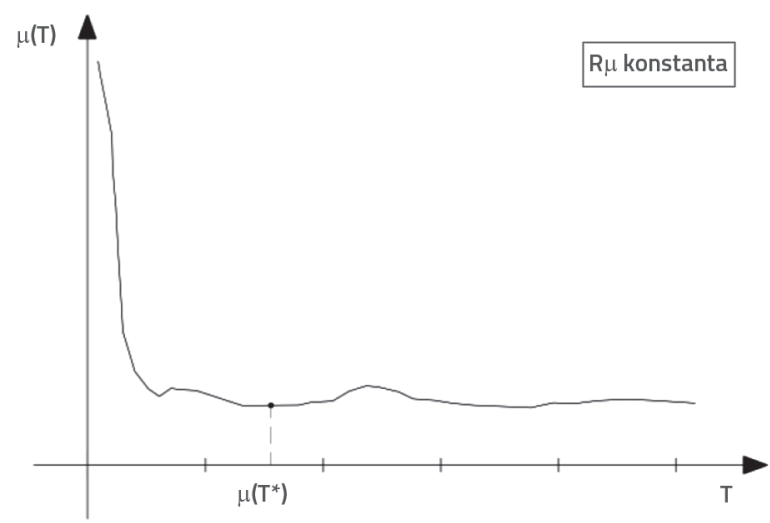

Figure 3. Determination of ductility demand $\mu(T)$ using constant $R_{\mu}$ strength spectrum [1]

\subsection{Determination of constant ductility inelastic spectrum}

In order to compute target displacement, graphic representation can be used to plot the constant ductility inelastic spectrum associated with the previously determined $\mu$ ductility value. If analytical calculations are performed, then only the ductility $\mu$ for the period $T^{*}$ - not for all spectrum of periods - has to be determined.

Unlike the CSM and the N2 method, which make use of inelastic smoothed design spectra, the capacity diagram does not intersect the demand diagram in the graphic variant of the proposed method.

However, if the ascendant slope of the bilinearly idealised diagram is extended until its intersection with the constant ductility inelastic spectrum, then the target displacement $D_{t}^{*}$ of the equivalent system can be obtained (Figure 2). Alternatively, after having determined the ductility demand according to Section 2.3 of this paper, the calculation of the target displacement $D_{t}$ of the MDOF system can be initiated on an analytical path, with the following expression, similarly for the N2 and proposed methods.

$D_{t}=\Gamma \cdot \mu \cdot D_{y}^{*}$

In Eq. (6) the product represents the target displacement $D_{t}^{*}$ of the SDOF system, the same as the intersection of the ascendant slope of the bilinear capacity diagram and the constant ductility inelastic spectra [1]. 


\section{Numerical results}

\subsection{Summary of application of proposed method}

The key steps of the proposed methodology have been described in a previous work of the authors [1]. For the sake of brevity, these steps are summarised as follows:

1. Determine capacity curves of each analysed structure, through pushover analysis.

2. Linearly idealise the capacity curves and calculate main quantities of the equivalent SDOF system: period $\mathrm{T}^{*}$, yield acceleration $S_{a y^{\prime}}$ yield displacement $D_{y^{\prime}}^{*}$ and ultimate displacement $D^{*}$. This step of the procedure is similar to the methodology adopted in EC8 (N2 method). An example that meets requirements of the $\mathrm{N} 2$ and also those of the proposed method is presented in Sections 3.3, 3.4, and 3.5 of this paper.

3. Determine the elastic spectrum $S_{a e}(T)$ for each earthquake record, through SDOF response history analysis

4. Calculate the strength demand $R_{\mu^{\prime}}$ for each accelerogram and bilinear capacity diagram, as described in section 2.3 (Eq. (5)).

5. Calculate the ductility demand associated to the equivalent SDOF with the aid of the constant strength demand $\mathrm{R}_{4}$ spectrum, as described in Section 2.4. Different SDOF hysteretic modelling may yield different ductility demands.

6. Determine the inelastic displacement demand analytically or graphically, as in Section 2.4.

7. Perform a pushover analysis by pushing the structure to the target displacement; determine the effort state, displacements and rotations at the local level.

\subsection{Structures, materials and loading}

Three reinforced concrete frames with different height regimes $(5,9$, and 15 storeys) have been proposed for analysis, referred from now on as structures 1,2 , and 3 (Figure 4). The frames have two spans of 6 metres each. The span of the frames is $6 \mathrm{~m}$ in perpendicular plane. Dead loads, including the monolithic reinforced concrete slab, amount to 8 $\mathrm{kN} / \mathrm{m}^{2}$. The value of $4 \mathrm{kN} / \mathrm{m}^{2}$ is adopted for live loads [1].

The design meets the criteria established for the high ductility class (DCH), defined in EC8. The strength class of the chosen concrete is $\mathrm{C} 20 / 25$. The reinforcement has a yield strength of $\mathrm{f}_{\mathrm{yk}}=345 \mathrm{~N} / \mathrm{mm}^{2}$, characteristic to reinforcement used in Romania, before Eurocode 2 came into force. The cross-sections of structural elements are shown in Figure 5. They have a different reinforcement layout for the "lower storeys" and the "upper storeys".

\subsection{Plotting and bilinear idealisation of pushover curves}

As mentioned earlier, the main difference between the proposed method and the code-based NSA lies in the determination of inelastic demand. When it comes to the MDOF to SDOF equivalence of structural capacity (bilinearization of capacity diagrams), the proposed method adopts simplifications of the N2 method, and therefore the same capacity curves and bilinearization techniques can be used when comparing the proposed method to code-based NSA methods. Therefore, Sections 3.3, 3.4, and 3.5 of this paper describe in detail the calculations that are necessary for the code-based NSA, N2 method and the proposed method.

The capacity curves were plotted using the SeismoStruct [26] software package. Two types of lateral load distributions were considered. First, an invariable triangular load distribution, second, an adaptive force distribution, using the Displacement Based Adaptive Pushover [16] method. The latter force b)

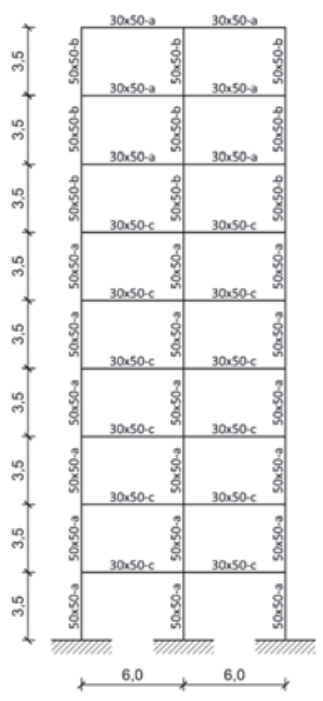

c)

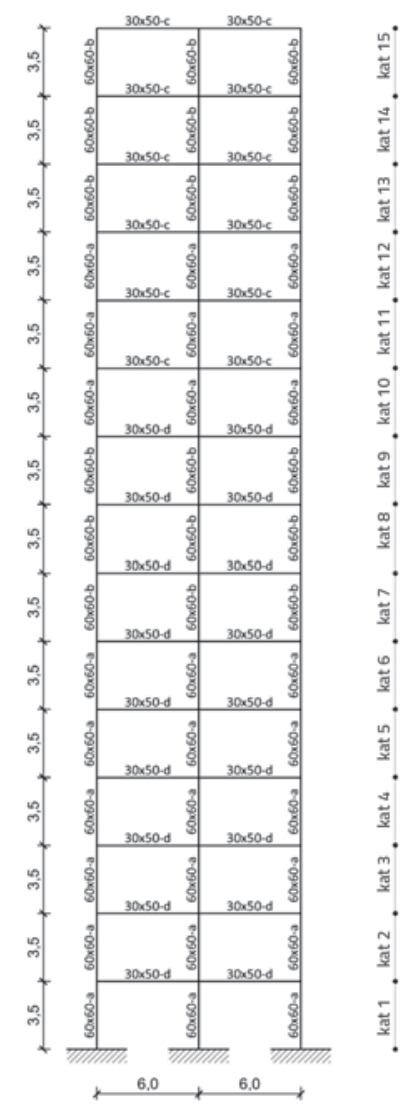

Figure 4. Geometrical properties of analysed structures: a) 5 storey structure; b) 9 storey structure; c) 15 storey structure [1] 


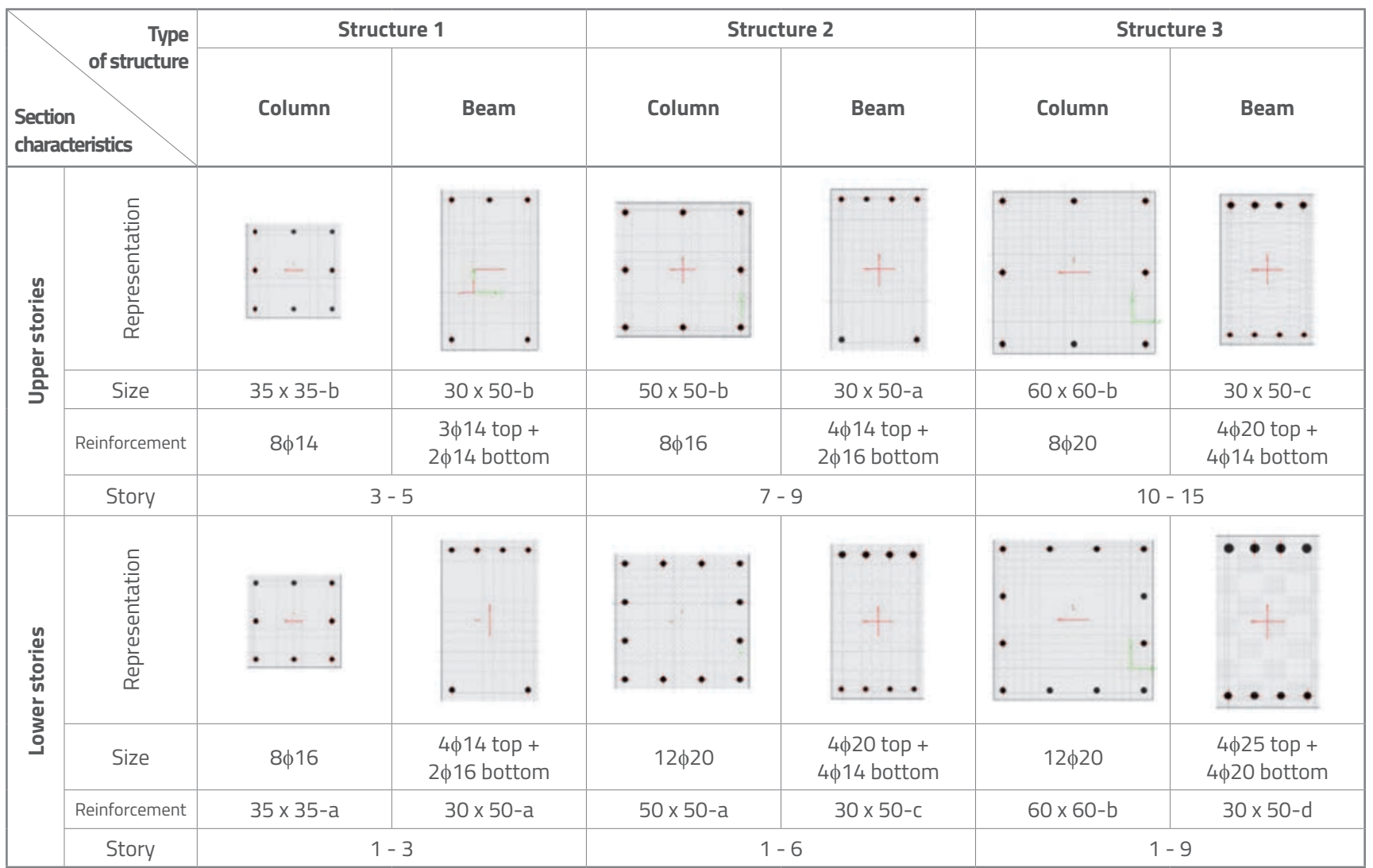

Figure 5. Reinforced concrete beam and column sections [1]

distribution was chosen for calculation as it has produced - in accordance with $[16,17,27]$, the best results in the context of advanced pushover methods.

The obtained capacity curves (Figure 6) are represented in the force-displacement format for the two types of the lateral force distribution used. In Figure 6, the F-D stands for the values of the MDOF system, and the $F^{*}-D^{*}$ stands for those of the equivalent SDOF system. To determine the characteristics of the equivalent SDOF system, namely the period $\mathrm{T}^{*}$ and yield displacement $\mathrm{D}_{\mathrm{y}^{\prime}}$ the $\mathrm{F}^{*}-\mathrm{D}^{*}$ format capacity curve is bilinearly idealised using the equal energy rule. The areas situated below the capacity curve represent the energy dissipated by the equivalent system. The sum of areas can be calculated by integrating the product of $\mathrm{S}_{\mathrm{a}}$ and $\mathrm{D}^{*}$. By imposing the equality between the yield and ultimate acceleration $\left(S_{a y}=S_{a u}\right)$, the yield displacement $D_{y}^{*}$ of the equivalent system can be computed analytically (Eq. (7) and Figure 7). Once the yield displacement $D_{v}^{*}$ is determined, the equivalent period $T^{*}$ can be calculated: it defines the angle of the ascendant slope of the bilinear system through Eq. (8) [1].

The results obtained regarding yield displacements $D_{y^{\prime}}^{*}$ yield accelerations $\mathrm{S}_{\mathrm{ay}}$ and dissipated energy $\mathrm{E}_{\mathrm{m}}^{*}$ (for three analysed structures and two lateral force distributions) are presented in Table 1 and Table 2. Alternatively, target displacements through code-based NSA are also determined graphically, as shown in Figure 8.

$$
\begin{aligned}
& D_{y}^{*}=2 \cdot\left(D_{u}^{*}-\frac{E_{m}^{*}}{F_{y}^{*}}\right) \\
& T^{*}=2 \cdot \pi \cdot \sqrt{\frac{m^{*} \cdot D_{y}^{*}}{F_{y}^{*}}}
\end{aligned}
$$

\subsection{Determination of inelastic seismic demand}

Seismic records chosen are the ones recorded during large Vrancea (Romania) intermediate depth earthquakes, which are generally characterized by both narrow and wide frequencies. The seismic data for the current application were farfield earthquakes, matched to the intensity (peak ground acceleration) of the code-based spectra.

Eight accelerograms have been matched to the design spectrum according to the Romanian design code. The design spectrum matched accelerograms were generated using the SeismoMatch software [28], and in compliance with rules formulated in Section 3.2.3.1.2 of EC8. The smoothed elastic design spectrum and the elastic spectra obtained from the original and the matched accelerograms are plotted in Figure 9 [1].

It should be noted that accelerogram scaling is necessary only to facilitate comparison of the proposed procedure that uses 

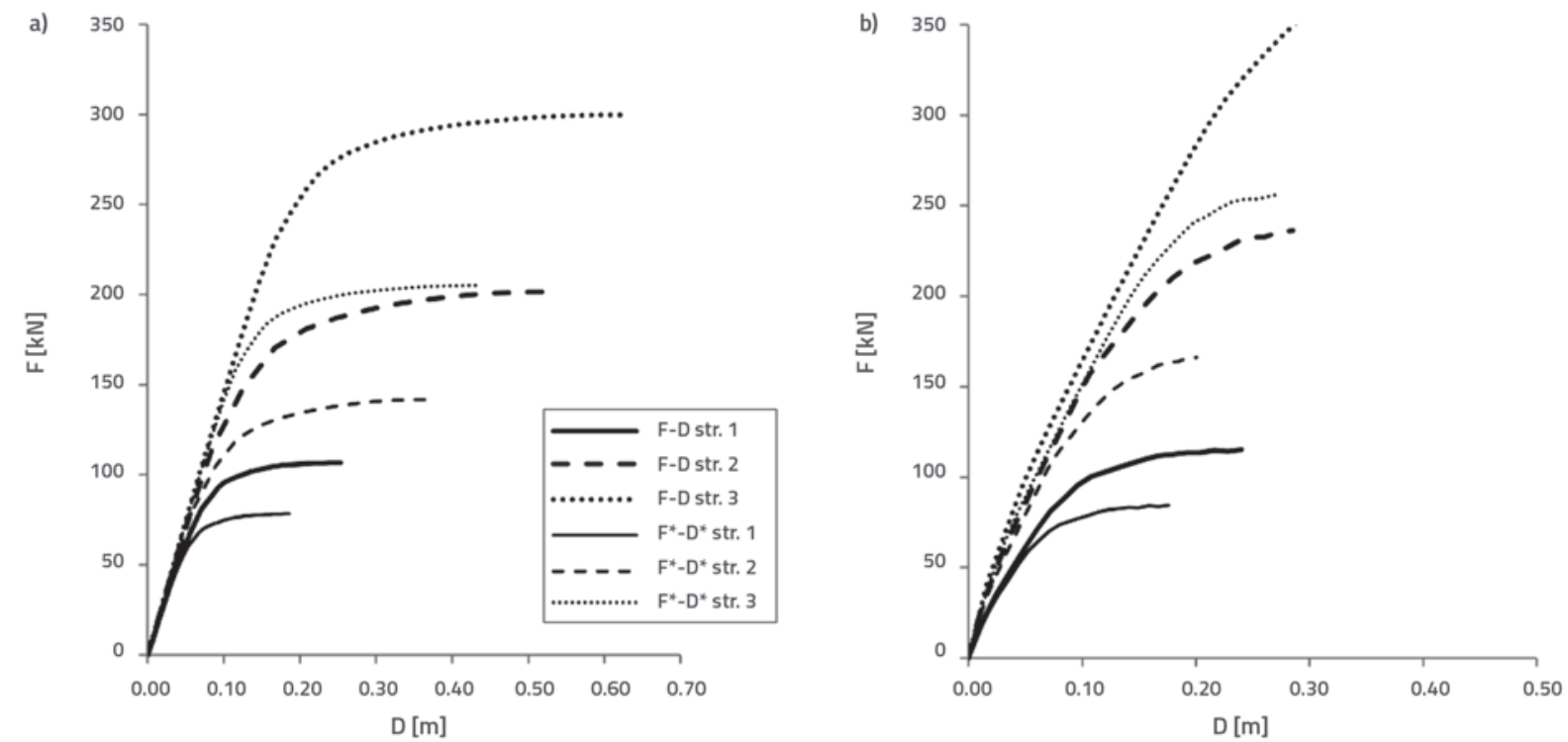

Figure 6. Capacity (pushover) curves for the MDOF and equivalent SDOF systems: ) fixed (triangular) load pattern; b) adaptive (DAP) load pattern
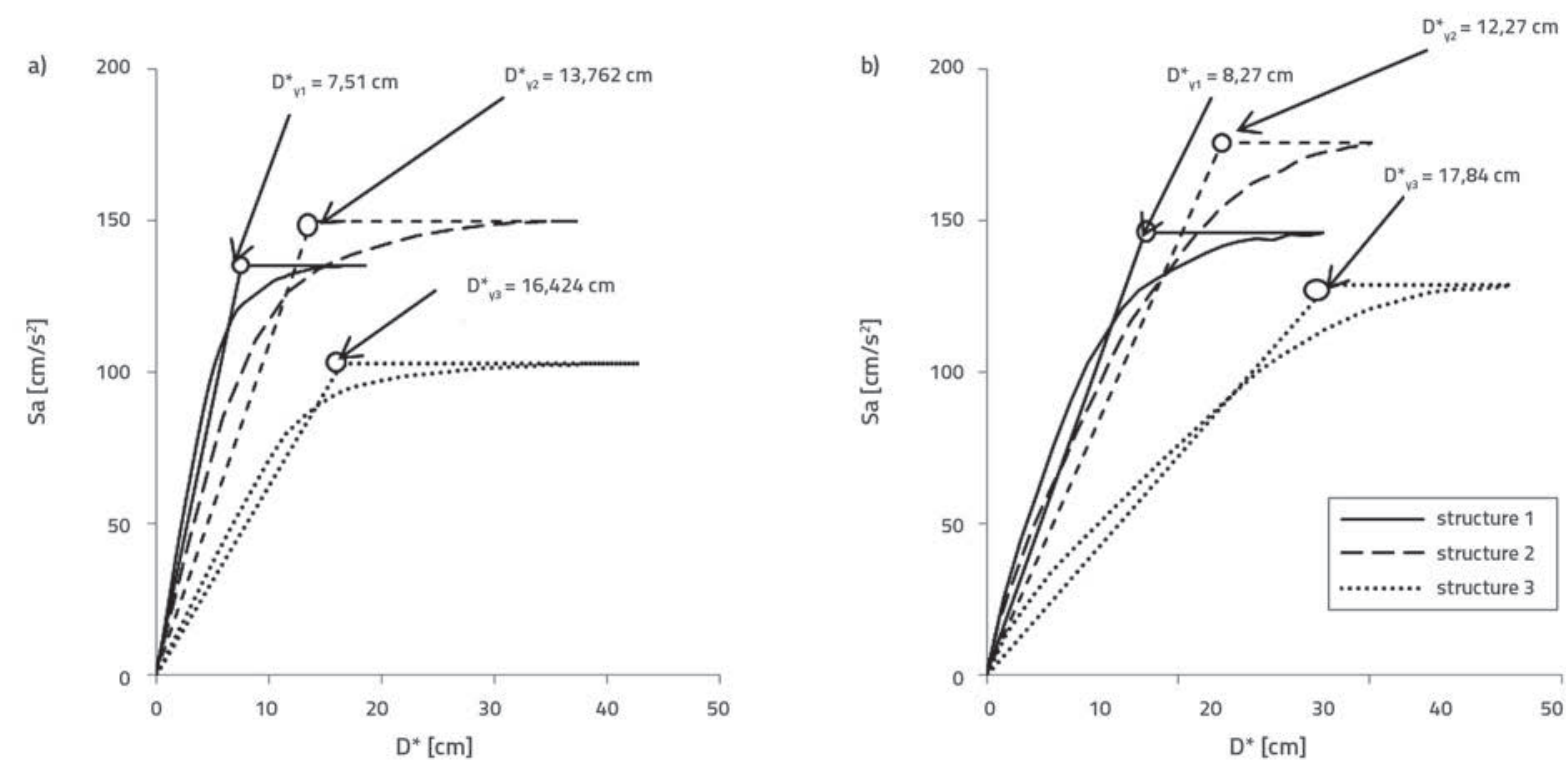

Figure 7. Bilinear capacity diagrams for equivalent SDOF systems: a) fixed (triangular) load pattern; b) adaptive (DAP) load pattern

Table 1. Summary of results for the equivalent SDOF system triangular load pattern

\begin{tabular}{|c|c|c|c|}
\hline $\begin{array}{r}\text { Type of } \\
\text { structure }\end{array}$ & $\begin{array}{r}\text { 5 storey } \\
\text { structure }\end{array}$ & $\begin{array}{c}\text { 9 storey } \\
\text { structure }\end{array}$ & $\begin{array}{c}\mathbf{1 5} \text { storey } \\
\text { structure }\end{array}$ \\
\hline $\mathrm{T}^{*}[\mathrm{~s}]$ & 1.480 & 1.900 & 2.512 \\
\hline$\Gamma[-]$ & 1.364 & 1.422 & 1.463 \\
\hline $\mathrm{S}_{\mathrm{ay}}\left[\mathrm{cm} / \mathrm{s}^{2}\right]$ & 135.334 & 149.799 & 102.755 \\
\hline $\mathrm{D}_{\mathrm{y}}^{*}[\mathrm{~cm}]$ & 7.514 & 13.762 & 16.434 \\
\hline $\mathrm{E}_{\mathrm{m}}^{*}[\mathrm{kNcm}]$ & 1157.54 & 4310.42 & 7145.34 \\
\hline
\end{tabular}

Table 2. Summary of results for the equivalent SDOF system adaptive load pattern

\begin{tabular}{|c|c|c|c|}
\hline $\begin{array}{r}\text { Type of } \\
\text { structure }\end{array}$ & $\begin{array}{r}\mathbf{5} \text { storey } \\
\text { structure }\end{array}$ & $\begin{array}{c}\text { 9 storey } \\
\text { structure }\end{array}$ & $\begin{array}{c}\mathbf{1 5} \text { storey } \\
\text { structure }\end{array}$ \\
\hline $\mathrm{T}^{*}[\mathrm{~s}]$ & 1.494 & 1.659 & 2.338 \\
\hline$\Gamma[-]$ & 1.364 & 1.422 & 1.463 \\
\hline $\mathrm{S}_{\mathrm{ay}}\left[\mathrm{cm} / \mathrm{s}^{2}\right]$ & 146.157 & 175.779 & 108.619 \\
\hline $\mathrm{D}_{\mathrm{y}}^{*}[\mathrm{~cm}]$ & 8.272 & 12.272 & 17.84 \\
\hline $\mathrm{E}_{\mathrm{m}}^{*}[\mathrm{kNcm}]$ & 1137.3 & 2314.4 & 4744.88 \\
\hline
\end{tabular}



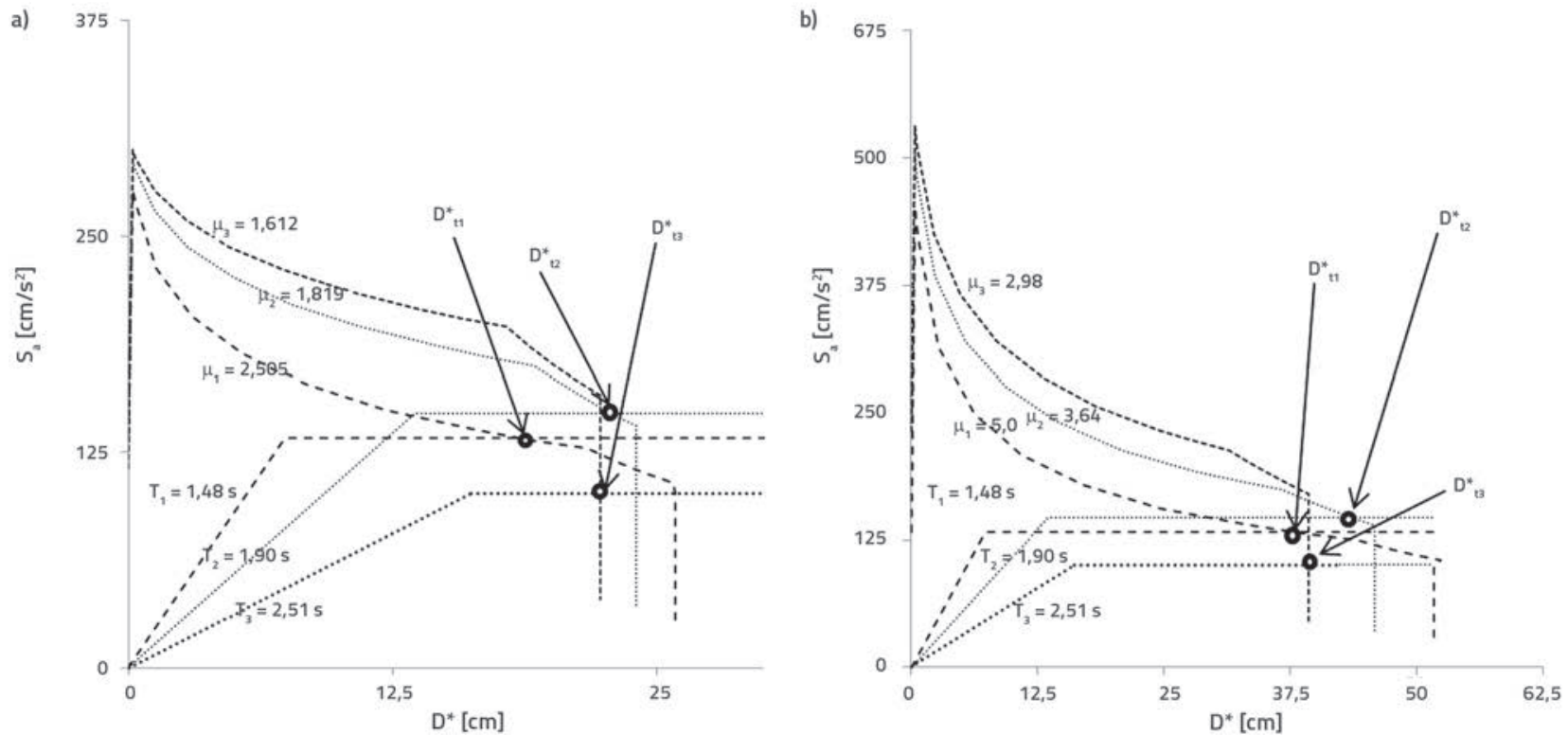

Figure 8. Determination of target displacement using graphical procedure (EC8) for design spectra characterised by: a) PGA $0.12 \mathrm{~g} ;$ b) PGA $0.24 \mathrm{~g}$
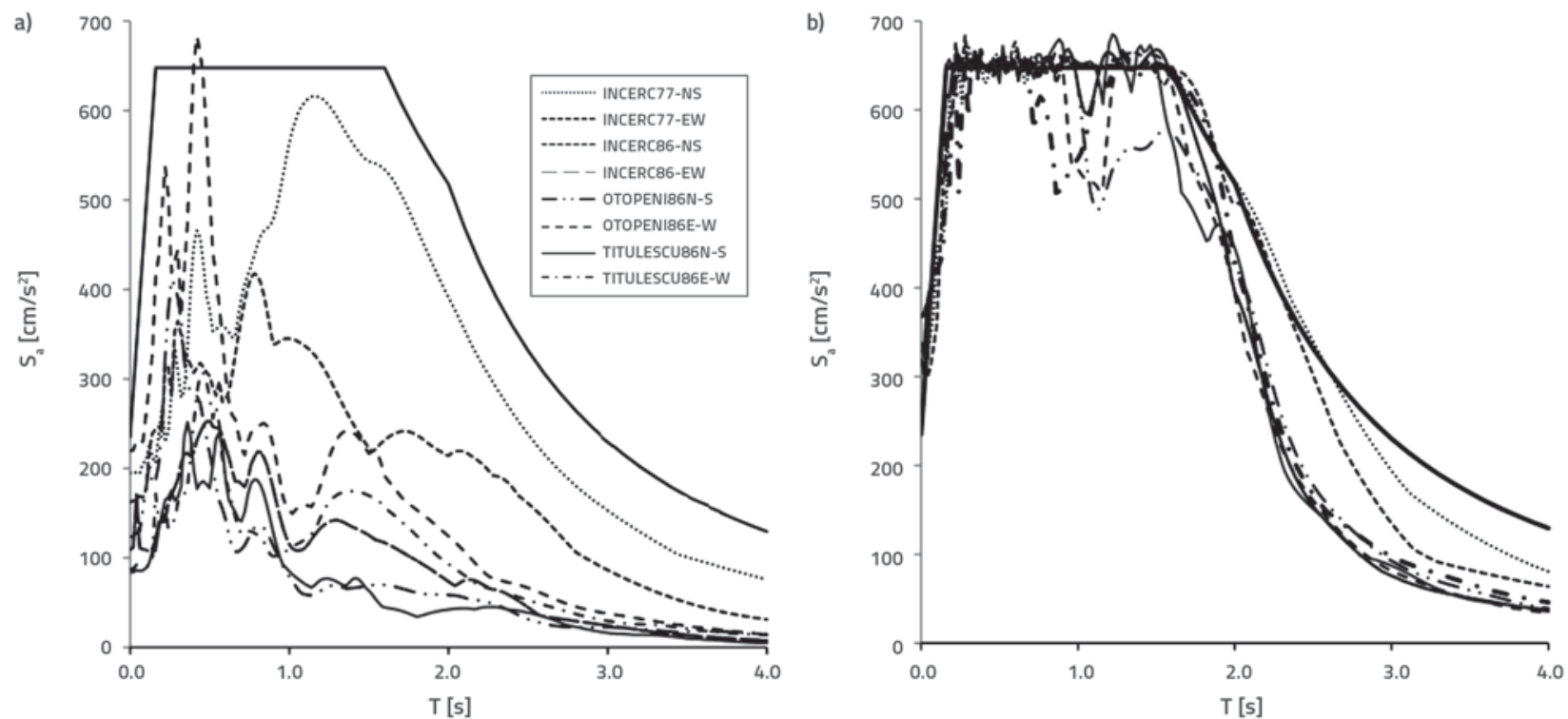

Figure 9. Elastic spectrum developed from: a) unmodified earthquake records; b) elastic spectrum developed from design spectrum matched records

accelerograms with the code based procedure, which employs smoothed design spectra. This step is not necessary for general use of the proposed procedure. This approach can be applied to every single accelerogram, without the need for accelerogram scaling or matching. This feature is one of the advantages of the proposed method compared to the code-based NSA, because the latter needs accelerograms that are compatible with a smoothed spectrum [23].

A total number of 384 nonlinear response history analyses of SDOF models were executed for the three analysed structures. The number of analyses is justified by the distinct analyses needed for the two types of load distributions in pushover analyses, eight different accelerograms scaled for two intensities, and four types of hysteretic models. A five percent value was assumed for viscous damping and the same percentage was assumed for the post-yield hardening.

The constant ductility inelastic spectra were generated using four types of hysteretic models: bilinear-elastic, bilinear-plastic with hardening, a Clough bilinear stiffness degrading model, and a modified Clough model (Figure 10). For the graphic representation of ductility demand, the elastic and inelastic spectra were generated for periods ranging from 0,1 s to $5 \mathrm{~s}$.

The assessed hysteretic models presented in Figure 10 are different from the definition of the loading-unloading cycles: (a) ignores the stiffness degradation effects, while $(b-d)$ takes into account the stiffness degrading effects. 
It is important to mention that the model (a) included here usually describes the inelastic behaviour of nonlinear elastic materials defined by the same branches for the loading and unloading behaviour (i.e. the remaining deformation is zero). This model is included in the group of hysteretic models discussed here because of its simplicity in modelling inelasticity, and as it reveals more clearly the importance and influence of more advanced hysteretic models adopted for modelling real cyclic behaviour of elastoplastic materials such as reinforced concrete elements. Some sensitivity studies concerning the influence of different hysteretic models will be discussed and highlighted in Section 4 and in the concluding section of this paper.

Models (a-c) are well-known, while model (d) is modified so as to "try to get more realistic behaviour during reloading" [29]. Just like model (c), it has deficiencies when reloading occurs [30]. The main difference in the modified Clough model is that on loading the response is directed towards the displacement reached in the previous load cycle, and it is applied when the force decreases to the value of 0 .

The constant strength demand $\mathrm{R}_{\mu^{\prime}}$ which is related to the yield/ ultimate acceleration $\mathrm{S}_{\mathrm{ay}}=\mathrm{S}_{\mathrm{au}}$ of the bilinear capacity diagram, and the period $\mathrm{T}^{*}$ of the SDOF equivalent, were determined in every case. Then the ductility demand $\mu$ was calculated through NTHA of the SDOF oscillator, characterised by period $\mathrm{T}^{*}$ and constant strength demand $\mathrm{R}_{\mu^{\prime}}$ as also described in Sections 2.3 and 2.4 . The constant strength and constant ductility spectra were developed using the Bispec [25] software.

\subsection{Determination of target displacements}

In the scope of application of the proposed method, the target displacement $D_{t}$ of the MDOF system has been calculated analytically through Eq. (6) as the product of the SDOF yield displacement, ductility demand $\mu$, and first mode participation factor $\Gamma$. As already presented, the graphic representation and determination of target displacement and constant ductility inelastic spectrum is also possible, as shown in Figure 2. The same pushover curves could be used to determine target displacements through the code-based NSA, as in the case of the proposed methodology [1]. The bilinearly idealised capacity curves and characteristics of the equivalent SDOF system are presented in Figure 7, Table 1, and Table 2.
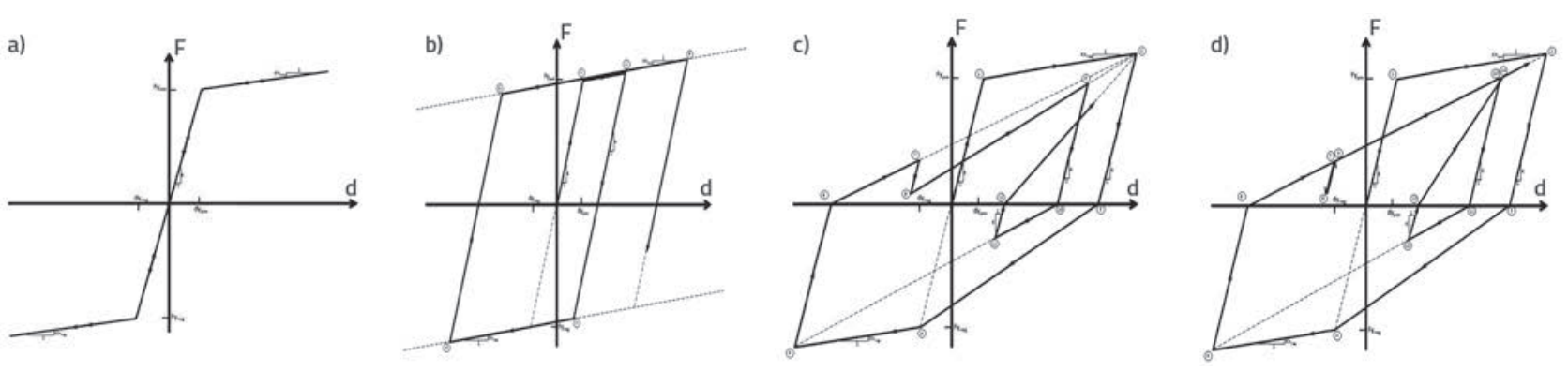

As mentioned previously, the target displacement $D_{t}^{*}$ of the SDOF system, as well $D_{t}$ of the MDOF system, can easily be determined. It is the product of the yield displacement $D_{y}^{*}$ of the SDOF system with ductility demand $\mu$ and participation factor in the first mode of vibration $\Gamma$ (Eq. (6)). The graphic determination of target displacements through the code-based NSA is shown in Figure 8.

\section{Discussion of results compared to other types of seismic analyses}

\subsection{Upper storey displacements}

Specific and mean upper storey displacements, obtained for the proposed method, are plotted in Figure 11 for each of the eight earthquakes and SDOF hysteretic models used. As mentioned above, seismic demands are represented by the design spectrum in case of the NSA, and the totality of the design spectrum matched seismic records, for the proposed method and the NTHA.

The nonlinear time-history analyses (NTHA) of the MDOF system were conducted using the same accelerograms for comparison purposes, and only to reveal the differences with regard to the proposed method that uses the NTHA of a SDOF oscillator. The difference in the proposed approach to the NTHA is depicted in Figure 2.b and 2.c. In the general use of the procedure, the NTHA of the MDOF system is not necessary.

The effectiveness of the method is revealed by comparison of upper storey displacements ("MEAN-TOT" in Figure 11) yielded

Figure 10. Hysteretic models used: (a) bilinear-elastic (b) bilinear-plastic with hardening, (c) Chough type model, (d) Modified Clough type model [25] 
Table 3. Summary of quantities obtained through code based NSAPGA $=0.12 \mathrm{~g}$

\begin{tabular}{|l|c|c|c|}
\hline $\begin{array}{r}\text { Type of } \\
\text { structure }\end{array}$ & $\begin{array}{r}\text { 5 storey } \\
\text { structure }\end{array}$ & $\begin{array}{c}\text { 9 storey } \\
\text { structure }\end{array}$ & $\begin{array}{c}\text { 15 storey } \\
\text { structure }\end{array}$ \\
\hline Parameters & 0.751 & 1.109 & 1.835 \\
\hline$T^{*}[s]$ & 1.480 & 1.900 & 2.512 \\
\hline$\Gamma[-]$ & 1.364 & 1.422 & 1.463 \\
\hline$S_{a e}\left(T^{*}\right)\left[\mathrm{cm}^{*} \mathrm{~s}^{2}\right]$ & 323.700 & 272.600 & 165.700 \\
\hline $\mathrm{S}_{\mathrm{ay}}\left[\mathrm{cm} / \mathrm{s}^{2}\right]$ & 135.334 & 149.799 & 102.755 \\
\hline $\mathrm{R}_{\mu}[-]$ & 2.391 & 1.819 & 1.612 \\
\hline$\mu[-]$ & 2.505 & 1.819 & 1.612 \\
\hline$D_{y}^{*}[\mathrm{~cm}]$ & 7.514 & 13.762 & 16.434 \\
\hline$D_{t}^{*}[\mathrm{~cm}]$ & 18.822 & 25.033 & 26.492 \\
\hline$D_{t}[\mathrm{~cm}]$ & 25.670 & 35.596 & 38.757 \\
\hline
\end{tabular}

by the totality of proposed method analysis, with the mean upper storey displacement of the entirety of NTHA-S (NTHA), and of the code based NSA.

It can easily be seen in Figure 11 that displacements determined with the help of bilinear elastic models are distinguished through significant errors. When results obtained using the bilinear elastic model are excluded from the mass of the results (depicted with "MEAN-WO BE"), mean relative errors are improved considerably: 1.13;1.33 instead of $1.23 ; 1.42$ for the 5 storey structure and $1.33 ; 1.45$ instead of $1.42 ; 1.61$ for the 9 storey structure. As to the standard deviation of upper storey displacements determined through the proposed method: $2.95 ; 7.35 \mathrm{~cm}$ instead of $5.80 ; 11.81 \mathrm{~cm}$ for structure 1 and $4.79 ; 7.30 \mathrm{~cm}$ instead of $6.57 ; 11.68 \mathrm{~cm}$, for structure 2 , were obtained when disregarding results obtained through the bilinear-elastic hysteretic model. Each two numbers separated by semicolon represent the mean relative errors occurring at the set of earthquakes with 0,12g and 0,24g, respectively.

Thus, when disregarding the results of the bilinear elastic model, the proposed procedure yields the best NTHA estimates, while performing better in all respects compared to the code-based NSA.
Table 4. Summary of quantities obtained through code based NSA $\mathrm{PGA}=0.24 \mathrm{~g}$

\begin{tabular}{|l|c|c|c|}
\hline $\begin{array}{r}\text { Type of } \\
\text { structure }\end{array}$ & $\begin{array}{c}\mathbf{5} \text { storey } \\
\text { structure }\end{array}$ & $\begin{array}{c}\mathbf{9} \text { storey } \\
\text { structure }\end{array}$ & $\begin{array}{c}\mathbf{1 5} \text { storey } \\
\text { structure }\end{array}$ \\
\hline Parameters & 0.751 & 1.109 & 1.835 \\
\hline$T^{*}[\mathrm{~s}]$ & 1.480 & 1.900 & 2.512 \\
\hline$\Gamma[-]$ & 1.364 & 1.422 & 1.463 \\
\hline $\mathrm{S}_{a e}\left(\mathrm{~T}^{*}\right)\left[\mathrm{cm} / \mathrm{s}^{2}\right]$ & 647.500 & 545.200 & 306.500 \\
\hline $\mathrm{S}_{\mathrm{ay}}\left[\mathrm{cm} / \mathrm{s}^{2}\right]$ & 135.334 & 149.799 & 102.755 \\
\hline $\mathrm{R}_{\mu}[-]$ & 4.784 & 3.640 & 2.983 \\
\hline$\mu[-]$ & 5.091 & 3.640 & 2.983 \\
\hline $\mathrm{D}_{\mathrm{y}}^{*}[\mathrm{~cm}]$ & 7.514 & 13.762 & 16.434 \\
\hline $\mathrm{D}_{\mathrm{t}}^{*}[\mathrm{~cm}]$ & 38.253 & 50.09 & 49.020 \\
\hline $\mathrm{D}_{\mathrm{t}}[\mathrm{cm}]$ & 52.177 & 71.22 & 71.71 \\
\hline
\end{tabular}
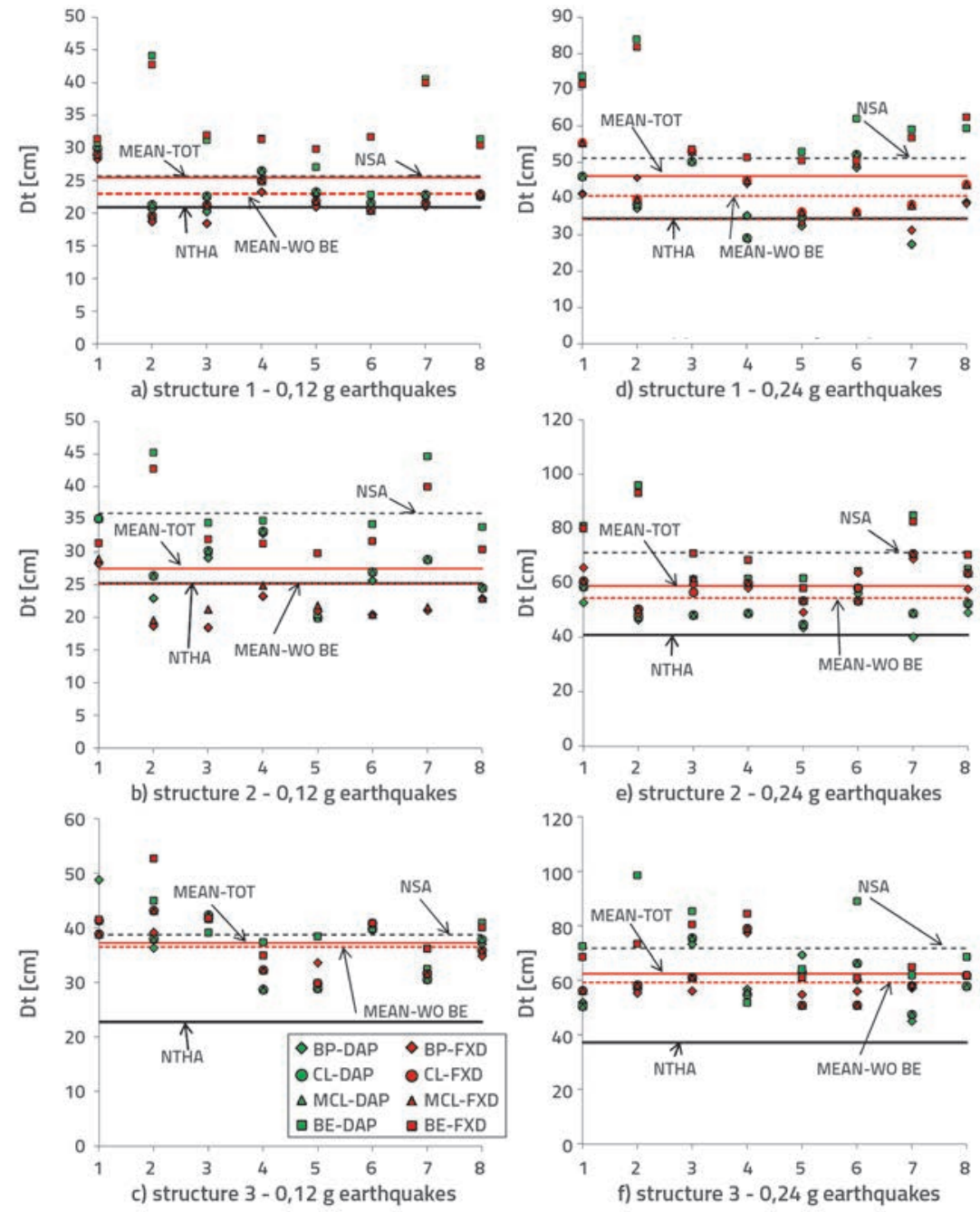

Figure 11. Top storey displacements for the proposed method, NTHA, and code-based NSA, for the frame structures: a) 5 storey, b) 9 storey, c) 15 storey (earthquake records with 0.12g PGA); and for the frame structures: d) 5 storey, e) 9 storey, f )15 storey (earthquake records with 0.24g PGA), DAP - Displacement Adaptive Pushover, FXD - Fixed (triangular) load distribution 
A similar conclusion could be drawn for each hysteretic model employed [1]: the proposed method does not significantly improve prediction of inelastic displacements in the case of the 15 storey structure.

As already mentioned, the seismic records used in this study are far-field earthquakes recorded during large-scale Vrancea (Romania) intermediate depth earthquakes, which are characterized by both low and high frequencies. The method presented herein has been previously applied on another type of seismic motion, a shallow depth event, namely on the Friuli 1976 earthquake. The record was previously matched to the EC8 spectra, type $A$, and scaled to three intensity levels: $0,36 \mathrm{~g}, 0,42 \mathrm{~g}$ and $0,48 \mathrm{~g}$. Similar to present research, the results showed that the method yielded better results than the code based NSA, and the upper storey displacements were in fair agreement with the NTHA [32].

\subsection{Lateral storey drifts}

The target displacement is calculated in NSA applications, and then the structure is pushed to the predetermined level (upper storey displacement) in order to calculate the state of demands and displacements in the structure, in this case the storey drift profile. In Section 4.1, it is clearly shown that the adopted SDOF hysteretic modelling influences the determined value of target displacement. It can also be observed that in this case a more sophisticated hysteretic modelling yields better target displacement estimates. When coming to storey drift profile calculations in NSA applications, which is the case of the proposed method, the pushover analysis is used to "push" the structure to the predetermined value of target displacement. As also stated in the literature, top displacements (depicted by pushover curve) corresponding to failure are "(single) deterministic values, because these methods do not take the specific input motions into account" [27]. Thus, when pushing the structure to the pre-determined (target) displacement the influence of the SDOF hysteretic modelling (but also approximations like MDOF to SDOF transformation using the first mode of vibration) are reflected in a single value only, which is the pre-calculated target displacement. This drawback is one of the widely accepted (and major) limitations of the procedure, and is related to the "static" nature of the method. As a consequence, in the NSA, the predicted storey drift values are influenced mostly by nonlinear modelling of members and lateral load distribution. The importance of nonlinear modelling of structural members is generally understated in NSA applications. The authors emphasize this importance and also the influence of modelling in $[1,2]$ and also in this paper. Regarding lateral load distribution, several other researchers concluded that exact reproduction of dynamic analysis response cannot be achieved by adaptive or non-adaptive pushover" [33]; and "in the highly inelastic range it tends to introduce excessive forces at the locations of plastic hinges and, to sub- overestimate the drift values at such storeys. They fail to reproduce accurately the local dynamic response characteristics of buildings, particularly within the post-peak range".

In this context, a comparative analysis of the (maximum) storey drift distribution is presented in this section, where the proposed method using pushover analysis with fixed and adaptive load pattern is set against the code based NSA procedures and nonlinear time-history analysis (NTHA). The influence of distinct hysteretic models within the proposed procedure is analysed with respect to [1]. The story drift profiles, with the corresponding mean error for the set of 8 earthquakes scaled on two intensity levels, are presented in Figures 12 and 13.

Mean storey drift values determined by the proposed method for the totality of the ground motions are relevant for the user, as related to NTHAs results for the totality of ground motions. The comparison is presented in Figures 12 and 13, where storey drift profiles determined via the smoothed design spectra are also depicted.

The same structures were analysed in [1], also based on the advanced pushover analysis procedure NEFCAD [21] in two variants: with and without taking in consideration nonlinear geometric effects, while lateral loads were invariable (triangular). In [1], only the Clough type stiffness degrading hysteretic model was used in the development of inelastic spectra.

The present study assesses the use of four hysteretic models, as shown in Figure 10. In Figures 12 and 13, lateral drift estimations are depicted for the mean target displacement value determined for the totality of ground motions (inelastic spectra), plotted for the hysteretic models used.

Nevertheless, concerning the code-based NSA, the drift profiles determined from the proposed method - in the case of 5 and 9 storey structures - constitute better approximations of the NTHA drift profiles.

On the one hand, the latter improvement is mostly due to the adaptive lateral force distribution, which follows more precisely the structure's elastoplastic incursions. On the other hand, it is due to the proposed more rigorous determination of inelastic demands, which take into account the actual frequency content of the earthquake. In contrast to this, the same lateral load drift profile is indicated in the code-based NSA, for two earthquakes with different frequency contents, but which yield the same target displacement.

In the case of the 15 storey structure, the proposed analysis method with adaptive force distribution yields an improved estimation of storey drifts in the lower storeys, compared to the analysis using invariable force distributions. This consideration is even more righteous in the case of $0.24 \mathrm{~g}$ earthquake records when incursions in inelastic domains are greater. As for the upper storeys, the storey drifts are overestimated in the case of the proposed method with adaptive force distribution, as opposed to the proposed method with invariable force distributions, which produces better estimates in this domain. 

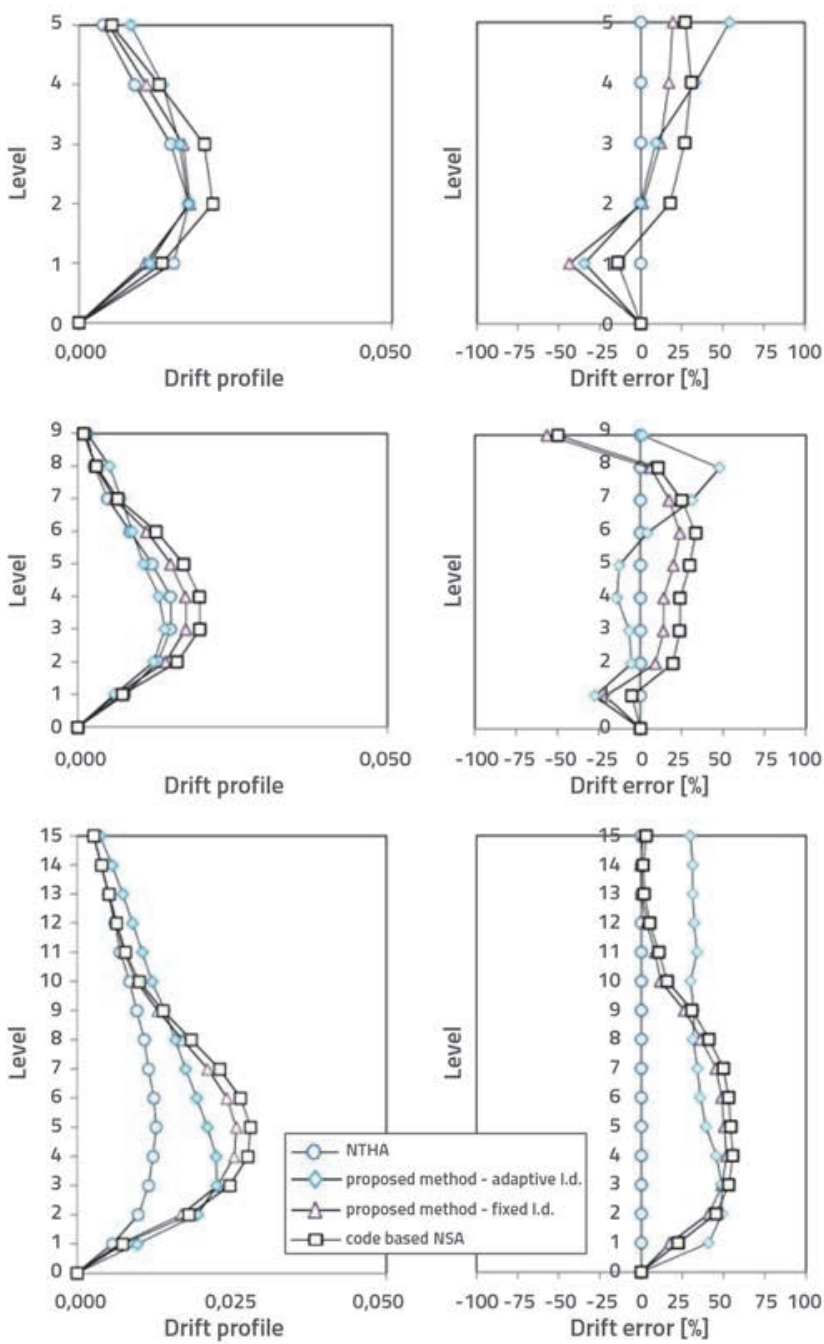

Figure 12. Drift profiles and errors calculated for eight earthquake records for the frame structures: a) $\mathbf{5}$ storey; b) 9 storey; c) 15 storey; PGA $=0.12 \mathrm{~g}$

\section{Conclusions}

This paper presents a new computer method through which upper storey displacements of two-dimensional RC frame structures can be determined extremely fast and with sufficient accuracy for a set of registered earthquake records, using the pushover analysis of the MDOF structural system and the NTHA of an SDOF oscillator. Compared to the NTHA of the MDOF, the proposed method has the main advantage of speed, repeatability and graphical representation of seismic capacity and demand through the spectral acceleration-displacement format.

The method can be applied in the framework of the NSA procedure proposed in Eurocode 8.

For low-and mid-rise structures, the proposed method produced reasonable estimates of the upper storey displacements obtained by NTHA. As compared to the code-based NSA, the
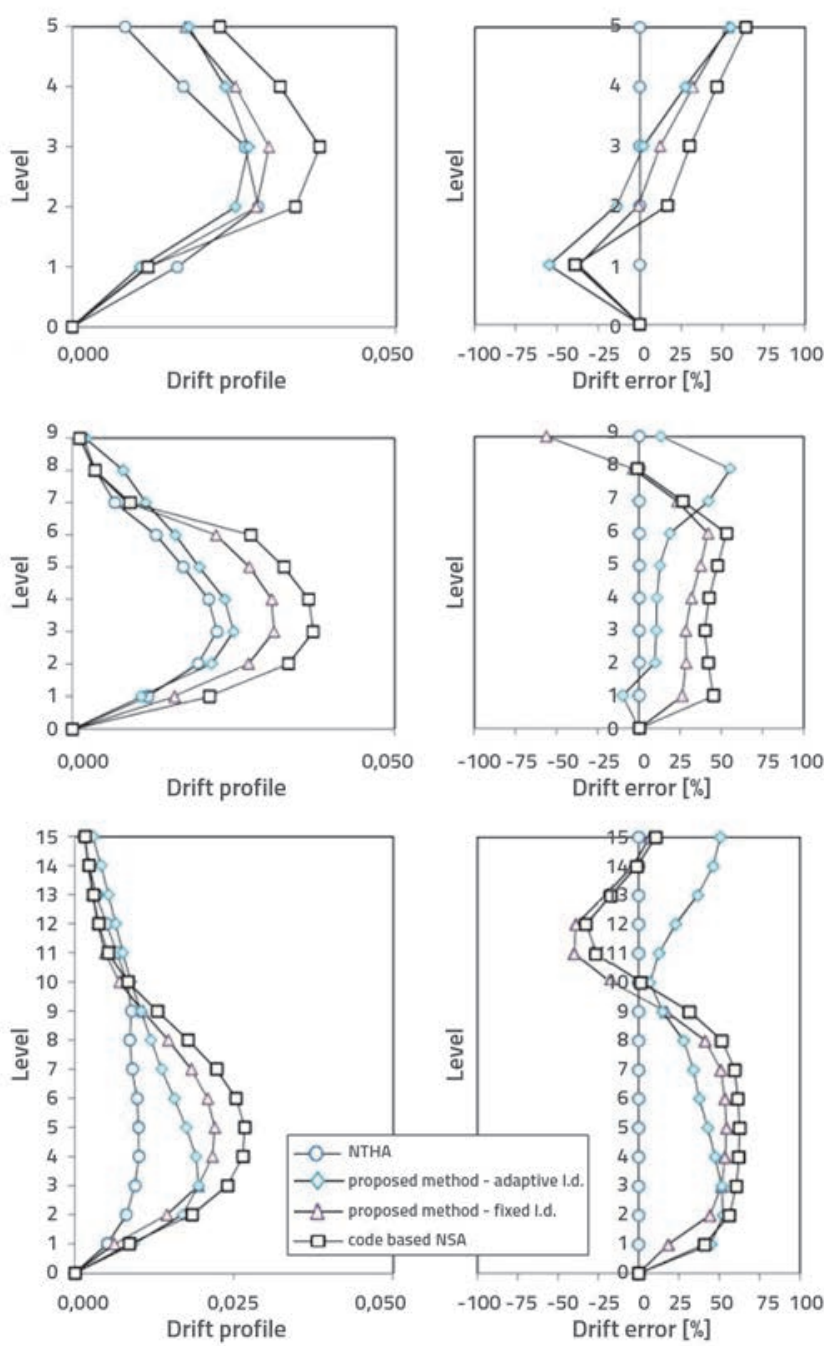

Figure 13. Drift profiles and errors calculated for eight earthquake records for the frame structures: a) 5 storey; b) 9 storey; c) 15 storey; $\mathrm{PGA}=0.24 \mathrm{~g}$

estimates of upper storey displacements have been improved in each case by using the proposed approach.

Compared to the analysis performed using the bilinear elastic model, the analyses using stiffness degrading, and bilinearplastic hysteretic models - used in the determination of the ductility demand - produced improved estimates of upper storey displacements.

In current application, the hysteretic modelling of the SDOF system influences the storey drift value only. Regarding the shape of the storey drift profile, the modelling of nonlinearities and of the incremental distribution of the rigidities (lateral loading) has an overwhelming influence. In other words, the hysteretic modelling of the SDOF cannot change the course of the storey drift profile, i.e. it has only a slight influence on the value of storey drifts. The storey drifts calculated by the NTHA cannot even be reasonably approximated by either of the variants of the proposed method, in the case of the 15 
storey structure. Thus, from the point of view of storey drift determination, the proposed method cannot overstep the limitations reported in the literature $[16,17,27,33]$.

Eurocode 8 recommends invariable load distributions for pushover analysis. However, the proposed method applied with the use of adaptive force distributions yielded better estimates of upper storey displacements and storey drifts. The improvement has been achieved even though in adaptive pushover the deformed shape is not constant throughout the analysis so that the MDOF-SDOF transformations are not conceptually accurate.

\section{REFERENCES}

[1] Varga, S., Chiorean G.C.: A Computer Method for Advanced Pushover Analysis of Reinforced-Concrete Frameworks, in Proceedings of the $15^{\text {th }}$ International Conference on Civil, Structural and Environmental Engineering Computing, Prague, 2015.

[2] Varga, S., Chiorean G.C.: Seismic Assessment of Reinforced Concrete Frameworks Through Advanced Pushover Analysis and Nonlinear Response of A SDOF Oscillator, Journal Procedia Engineering, 161 (2016), pp. 332-336.

[3] Fatahi, B., Hamid Reza, S.: Fully nonlinear versus equivalent linear computation method for seismic analysis of midrise buildings on soft soils." International Journal of Geomechanics, 14 (2013) 4, pp. 401-416.

[4] Deierlein, G.G., Reinhorn, A.M., Willford, M.R.: Nonlinear structural analysis for seismic design. NEHRP seismic design technical brief, 4 (2010), pp.1-36. 2010.

[5] ATC, ATC-40: Seismic Evaluation and Retrofit of Concrete Buildings, Redwood City, CA: Applied Technology Council, 1996.

[6] FEMA, Report FEMA 356: Prestandard and commentary for the seismic rehabilitation of buildings: Federal Emergency Management Agency, 2000.

[7] FEMA, Report FEMA 440: Improvement of nonlinear static analysis procedures. Washington, DC: Federal Emergency Management Agency, 2005.

[8] CEN, EN 1998-1: Eurocode 8, Design of structures for earthquake resistance; Part 1: General rules, seismic actions and rules for buildings. Brussels: Comite Europeen de Normalisation, 2004.

[9] Krawinkler, H., Seneviratna, G.D.P.K.: Pros and cons of a pushover analysis of seismic performance evaluation, Engineering Structures, 20 (1998) 1, pp. 452-464, http://dx.doi.org/10.1016/ S0141-0296(97)00092-8

[10] Chopra, A.K., Goel, R.K.: A modal pushover analysis procedure for estimating demands for buildings: Theory and Preliminary Evaluation, Earthquake Engineering and Structural Dynamics, 31 (2002) 3, pp. 561-582, http://dx.doi.org/10.1002/eqe.144

[11] Paret, T.F., Sasaki, K.K., Eilbeck, D.H.: Approximate inelastic procedures to identify failure mechanism from higher mode effects, in Proceedings of the $11^{\text {th }}$ World Conference on Earthquake Engineering, vol. 2, Paper no. 966. Acapulco, Mexico, 1996,
The studies carried out in this paper show that the proposed method provides better results in estimating the upper storey displacements in the case of low- and mid- rise structures, while in the case of high-rise structures the estimates did not differ significantly, with regard to the code-based NSA. Therefore, the best results were achieved for structures that are dominantly governed by the first mode of vibration. Further research is envisaged in the sphere of implementation of refined techniques that allow definition of the SDOF equivalent and bilinearization of the capacity curve, which take into consideration not only the first mode participation factor, but also the effect of higher vibration modes.

[12] Balić, I., Mihanović, A., Trogrlić, B.: Target acceleration in multimodal pushover method for R/C frames, Gradevinar, 65 (2013) 4, pp. 305-318.

[13] Bracci, J.M., Kunnath, S.K., Reinhorn, A.M.: Seismic Performance and Retrofit Evaluation of RC Structures, Journal of Structural Engineering, 123 (1997) 1, pp. 3-10, http://dx.doi.org/10.1061/ (ASCE)0733-9445(1997)123:1(3)

[14] Requena; M., Ayala, G.A.: Evaluation of a simplified method for the determination of the nonlinear seismic response of RC frames, in Proceedings of the $12^{\text {th }}$ World Conference on Earthquake Engineering, Auckland, New Zealand, 2000.

[15] Gupta, B., Kunnath, S.K.: Adaptive spectra-based pushover procedure for seismic evaluation of structures, Earthquake Spectra, 16 (2000) 2, pp. 367-391, http://dx.doi.org/10.1193/1.1586117

[16] Antoniou, S., Pinho, R.: Development and verification of a displacement-based adaptive pushover procedure, Journal of Earthquake Engineering, 8 (2004) 5, pp. 497-522, http://dx.doi. org/10.1080/13632460409350504

[17] Shakeri, K., Shayanfar, M.A., Kabeyasawa, T.: A story shear-based adaptive pushover procedure for estimating seismic demands of buildings," Engineering Structures, 32 (2010) 1, pp. 174-183, http://dx.doi.org/10.1016/j.engstruct.2009.09.004

[18] Varga, S.: An Alternative Method For The Determination of Inelastic Displacements Using Pushover Analysis and Directly Generated Inelastic Spectra, Acta Tehnica Napocensis, 57 (2014) 1, http:// constructii.utcluj.ro/ActaCivilEng/download/atn/ATN2014(1)_8. pdf

[19] Genkturk, B., Elnashai, A.S.: Development and application of an advanced capacity spectrum method, Engineering Structures, 30 (2008), pp. 3344-3354.

[20] Freeman, S.A.: Prediction of Response of Concrete Buildings to Severe Earthquake Motion, ACI Special Publication 55, 1978.

[21] Chiorean, C.G.: A computer method for nonlinear inelastic analysis of $3 \mathrm{D}$ composite steel-concrete frame structures," Engineering Structures, 57 (2013), pp. 125-152.

[22] Aschheim, M., Black, E.F.: Yield point spectra for seismic design and rehabilitation, Earthquake Spectra, 16 (2000) 2, pp. 317-336, http://dx.doi.org/10.1193/1.1586115 
[23] Fajfar, P.: A Nonlinear Analysis Method for Performance Based Seismic Design, Earthquake Spectra, 16 (2000) 3, pp. 573-592, http://dx.doi.org/10.1193/1.1586128

[24] Chopra, A.K.: Dynamics of Structures: Theory and Applications to Earthquake Engineering, $4^{\text {th }}$ ed.: Prentice Hall/Pearson Education, 2012.

[25] Hachem, M.M.: BISPEC. Interactive software for the computation of unidirectional and bidirectional nonlinear earthquake spectra, version 2.20, 2012, Help manual. http://www.eqsols.com/Pages/ Bispec.aspx

[26] SeismoSoft. (2014) SeismoStruct - A Computer Program for Static and Dynamic Nonlinear Analysis of Framed Structures (Help file), (online), http://www.seismosoft.com.

[27] Ferracuti, B., Pinho, R., Savoia, M., Francia, R.: Verification of displacement-based adaptive pushover through multi-ground pushover analyses, Engineering Structures, 8 (2009) 31, pp.178999, http://10.1016/j.engstruct.2009.02.035

[28] SeismoSoft. (2013), SeismoMatch, version 2.0.0, http://www. seismosoft.com/en/download_details.aspx?ID_Download=6.
[29] Otani, S.: Hysteresis models of reinforced concrete for earthquake response analysis. Journal of Faculty of Engineering, 36 (1981) 2, pp.407-441.

[30] JC Esquivel, Influence of some parameters on the inelastic earthquake response using different hysteretic models for reinforced concrete, 10 ${ }^{\text {th }}$ WCEE, Balkema, Rotterdam, 1992.

[31] Vidič, T., Fajfar, P., Fischinger, M.: Consistent inelastic design spectra: strength and displacement, Earthquake Engineering \& Structural Dynamics, 23 (1994) 5, pp. 507-521, http://dx.doi. org/10.1002/eqe.4290230504

[32] Varga, S.: An alternative method for the determination of inelastic displacements using pushover analysis and directly generated inelastic spectra, Acta Technica Napocensis: Civil Engineering \& Architecture, 57 (2014) 1, pp. 66-74.

[33] Antoniou, S., Rui, P.: Advantages and limitations of adaptive and non-adaptive force-based pushover procedures. Journal of Earthquake Engineering, 8 (2004) 4, pp. 497-522. 